\title{
Perancangan Game IDO untuk Pembelajaran Kosa Kata Bahasa Inggris Menggunakan Construct 2
}

\author{
Suastika Yulia Riska ${ }^{1}$, Widya Adhariyanty Rahayu ${ }^{2}$ \\ ${ }^{1,2}$ Teknik Informatika, STMIK Asia Malang \\ ${ }^{1}$ suastikayr@gmail.com, ${ }^{2}$ widyariyanty@gmail.com
}

\begin{abstract}
ABSTRAK.
Bahasa inggris merupakan salah satu mata kuliah yang masih menjadi beban. hal tersebut dikarenakan kurangnya minat mahasiswa dalam belajar bahasa inggris, khususnya dalam memperbanyak kosa kata bahasa inggris. sehingga, dikembangkan game untuk meningkatkan kosa kata bahasa inggris. nama game dalam penelitian ini adalah "english with ido". Pengembangan game menggunakan construct 2. adapun konsep dari game ini adalah game platform yang dikombinasikan dengan kuis. pengujian game ini dilakukan secara uji fungsional dan kuisioner dengan jumlah 70 responden. adapun prosentase berupa aspek penilaian tampilan game menyatakan sangat setuju sebesar $74 \%$, prosentase durasi waktu menyatakan setuju sebesar $50 \%$, prosentase daya tarik mahasiswa untuk belajar menyatakan sangat setuju sebesar 52\%, prosentase kemudahan belajar menyatakan setuju sebesar $49 \%$, dan pentingnya game kosa kata menyatakan setuju sebesar $51 \%$. Secara keseluruhan responden menyatakan setuju dan sangat setuju dari penerapan game english with ido.
\end{abstract}

Kata Kunci : game edukasi; bahasa inggris; kosakata

\section{ABSTRACT.}

English is one of the subjects that is still a burden for students. This is because the lack of interest of students in learning English, especially English vocabulary. Thus, developed a game to improve the English vocabulary. The name of the game is "English With Ido". Game development using Construct 2. The concept of this game is a game platform combined with quizzes. Testing this game done in functional test and questionnaire with the number of 70 respondents. The percentage of the aspect of the assessment of the display of the game is very agree equal to $74 \%$, the percentage of time duration is agreeable by 50\%, the percentage of student attractiveness to learn is strongly agreed at 52\%, the percentage of ease of learning is agreed by 49\%, and the importance of vocabulary game is agreed at 51\%. Overall respondents agreed and strongly agree from the implementation of this game

Keyword : educational games; English; vocabulary

\section{PENDAHULUAN}

Bahasa Inggris merupakan bahasa internasional yang banyak digunakan di berbagai Negara, salah satunya di Indonesia. Saat ini bahasa inggris sudah menjadi kebutuhan masyarakat. Bahasa inggris tidak hanya penting untuk akademik, namun juga sebagai komunikasi. Bahkan saat ini bahasa inggris sudah diperkenalkan kepada anak sejak dini. Kelancaran komunikasi tergantung pada banyaknya kosakata yang dikuasai . Semakin banyak kosa kata yang dimengerti, maka juga akan meningkatkan keterampilan dalam menggunakan bahasa inggris. Sehingga, kosakata memiliki peranan yang sangat vital untuk meningkatkan ketrampilan bahasa, khususnya bahasa inggris.

Pada kenyataannya di dunia pendidikan kosakata bahasa inggris masih menjadi 
masalah bagi siswa. Beberapa siswa merasa kesulitan untuk menghafal kosakata bahasa inggris. Selain itu, siswa juga merasa bosan ketika harus menghafal kosa kata dari kamus. Oleh karena itu perlu adanya inovasi pembelajaran yang diberikan kepada siswa. Salah satunya dengan pengembangan media pembelajaran berbasis game [4]. Sejak dulu masyarakat telah beranggapan bahwa game merupakan suatu aktifitas yang bertujuan untuk bersenang-senang dan mengisi waktu luang [8]. Namun dengan berkembangnya zaman di bidang teknologi ini, membuat game berkembang pesat ke arah yang lebih penting, yaitu pendidikan [15]. Sebelumnya system pembelajaran yang berjalan secara konvensional mengandalkan adanya buku sebagai salah satu sarana pembelajaran [14]. Namun, media tersebut sering membuat siswa merasa bosan, dan kurang membuat siswa aktif ketika berada di dalam kelas. Pengembangan media pembelajaran yang menarik juga akan mempengaruhi tingkah laku siswa dalam menerima materi, yaitu lebih bersemangat, lebih interaktif, dan materi juga lebih terserap dengan baik [17].

Banyak media pembelajaran yang telah dikembangkan, khususnya media pembelajaran berbasis game [5]. Game merupakan format multimedia yang dapat digunakan sebagai alternative media pembelajaran dan sebagai sarana mengingat materi pembelajaran [10].Karena dengan menggunakan media pembelajaran ini, siswa tidak hanya belajar namun juga bermain. Beberapa game dari berbagai platform terus dikembangkan [13]. Dengan adanya pembelajaran berbasis game, pembelajaran akan lebih menyenangkan tanpa menghilangkan esensi ilmu yang disampaikan [16]. Hal tersebut dapat menghilangkan rasa jenuh dan rasa takut mahasiswa untuk belajar [1]. Selain itu dengan media pembelajaran berbasis game dapat meningkatkan keterampilan berfikir, yaitu teknik dalam bermain game untuk menyelesaikan kasus berbasis ilmu pengetahuan [12].

Dari beberapa penelitian yang dikembangkan terkait pengembangan game edukasi penelitian ini mengembangkan game kosa kata bahasa inggris. Tujuan game edukasi kosa kata bahasa inggris ini adalah menciptakan suasana proses belajar mengajar yang menyenangkan. Sehingga, mahasiswa lebih mudah dalam memahami kosa kata bahasa inggris khususnya kosa kata pada bidang informatika dan menejemen.

\section{PEMBAHASAN \\ Metode}

Penelitian ini dilaksanakan di program studi Teknik Informatika dan Manajemen, STMIK Asia Malang, Jalan Soekarno Hatta - Rembuksari 1A Malang dan STIE Asia Malang, Jalan Borobudur No. 21 Malang. Game ini dikembangkan pada platform personal computer $(P C)$ yaitu game yang dibuat untuk dijalankan di komputer [10]. Aplikasi yang digunakan dalam pembuatan game adalah construct 2. Metode pengembangan yang digunakan untuk melakukan analisa serta perancangan game kosa kata bahasa inggris adalah Metode Waterfall. Adapun tahap metode tersebut mencakup analisis masalah dan kebutuhan, perancangan, implementasi, pengujian, pengoperasian dan maintenance [6]. Nama dari game yang dikembangkan adalah "Game English With IDO" yang diambil dari kata "I do" yang berarti saya melakukan. Harapan dari game ini mahasiswa yang mempelajari game ini benar-benar melakukan pembelajaran dengan baik. Tahapan metode yang dikembangkan pada perancangan Game IDO ditunjukkan pada Gambar 1 


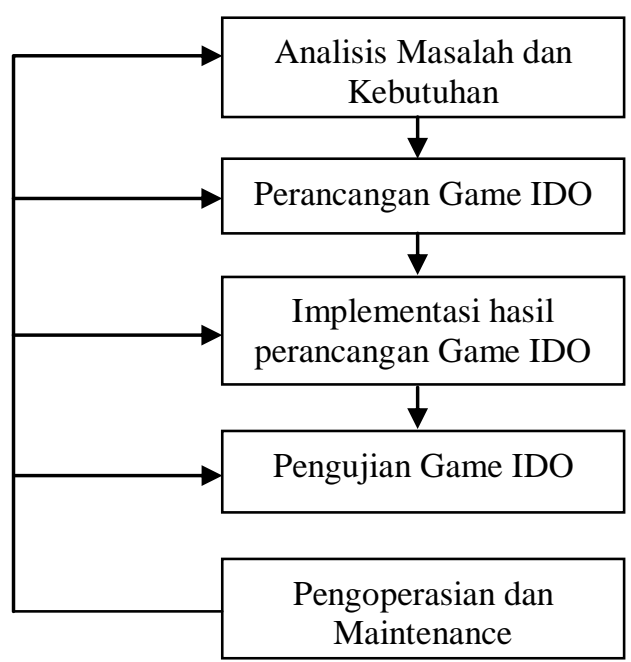

Gambar 1. Tahapan Pengembangan Game IDO dengan Metode Waterfall Tahap Analisis

Dari Gambar 1 menunjukkan bahwa awal pengembangan Game IDO dimulai dari melakukan analisa dari permasalahan yang terjadi pada mahasiswa ketika menempuh mata kuliah bahasa inggris. Adapun sasaran pengguna Game IDO adalah mahasiswa STMIK dan STIE ASIA Malang. Permasalahan yang banyak muncul dari mahasiswa yang menempuh kuliah bahasa inggris adalah kurangnya kosa kata bahasa inggris yang dimiliki mahasiswa. Sehingga, pada game ini dibuat kelompok kosa kata berdasarkan bidang informatika dan menajemen.

\section{Tahap Perancangan}

Tahap kedua dari perancangan game IDO adalah perancangan. Game ini dikembangkan menggunakan Construct 2. Adapun konsep dari game ini adalah game adventure sederhana yang dikombinasikan dengan kuis. Game adventure menggambarkan lingkungan dimana terdapat interaksi pemain untuk memecahkan masalah di dalam game [1]. Perancangan Game IDO dibuat dengan tujuan menghasilkan aplikasi yang dapat membuat proses membelajaran tidak monoton dan lebih menyenangkan [7]. Game IDO dibuat dengan system level. Tujuannya agar pengguna dapat memecahkan masalah dari yang paling mudah sampai dengan yang paling sulit [9]. Tahap perancangan game IDO meliputi pembuatan story board, pembuatan karakter, pembuatan layout (judul, background setiap level, next level, game over, halaman success, dan lain-lain).

Pembuatan karakter IDO digambarkan sebagai seorang mahasiswa ASIA Malang. Adapun karakter ido ditunjukkan pada Gambar 2.

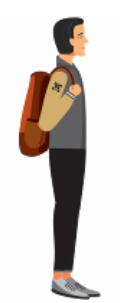

Gambar 2. Perancangan Sprite untuk Karakter IDO

Berdasarkan Gambar 2, karakter IDO digambarkan sebagai seorang mahasiswa dengan membawa tas, memakai sepatu, dengan pakaian yang rapi. Selain karakter IDO, perancangan layout game dibuat agar pengembangan game berjalan dengan lancar.

Perancangan layout untuk cerita game IDO ditunjukkan pada Gambar 3. 


\section{HALAMAN STORY}

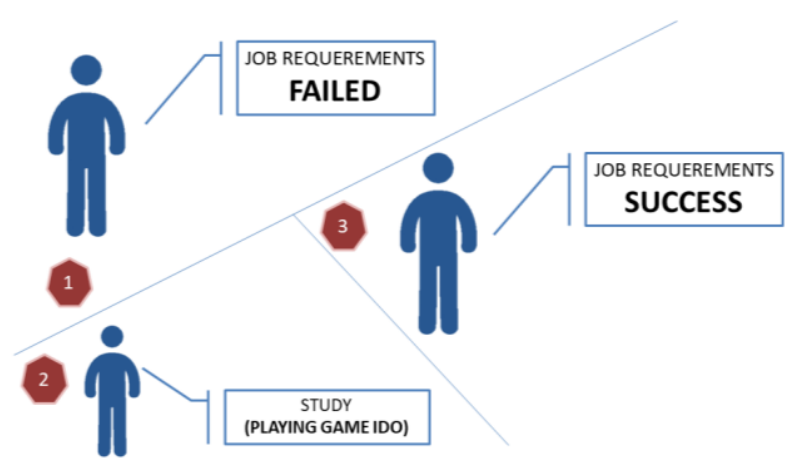

Gambar 3. Layout Halaman Story

Halaman story yang ditunjukkan pada Gambar 3 merupakan halaman cerita bergambar. Halaman ini dirancangan sebagai sebuah komik yang menceriterakan kisah seorang mahasiswa yang sulit mendapatkan pekerjaan karena kemampuan bahasa inggrisnya yang kurang. Kemudian dengan memainkan game IDO mahasiswa tersebut belajar banyak tentang kosa kata, yang merupakan dasar untuk mengembangkan kemampuan bahasa inggris. Sehingga, setelah sering memainkan game IDO mahasiswa tersebut berhasil memenuhi syarat untuk mendapatkan pekerjaan, khususnya dalam kemampuan bahasa inggris. Setelah user sampai di halaman story, user ada dihadapkan pada halaman study. Perancangan layout untuk halaman study ditunjukkan pada Gambar 4.

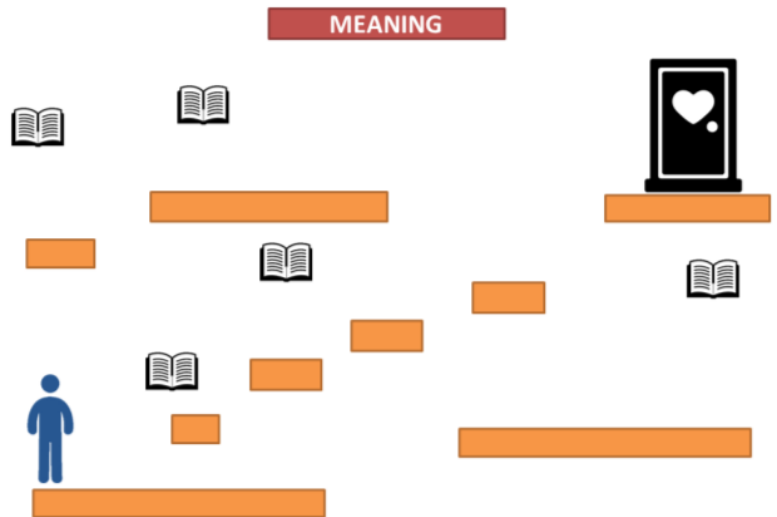

Gambar 4. Halaman Study

Pada halaman study user dihadapkan dengan game platform. User dapat memperbanyak perbendaharaan kosa kata bahasa inggris di bidang informatika dan bidang menejemen. User dapat berjalan, melompat, dan menuruni balok-balok yang tersedia di dalam halaman study. User dapat mengambil buku-buku yang didalamnya terdapat vocabulary bahasa inggris. Ketika buku tersebut diambil oleh user, maka pada kotak MEANING akan memunculkan arti dari vocabulary yang terdapat di dalam buku tersebut. Setelah user selesai mengambil semua buku, user bisa masuk ke dalam pintu untuk memulai kuis sesuai dengan bidangnya, yaitu informatika atau menejemen. Sebelum masuk halaman kuis, user akan memasuki halaman peta. Perancangan layout untuk peta di dalam game IDO ditunjukkan pada Gambar 5. 


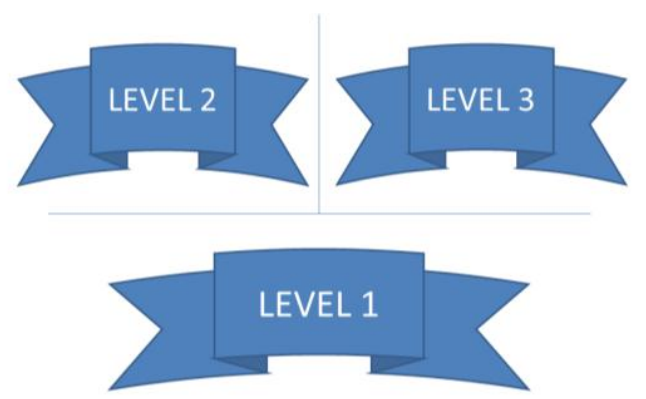

Gambar 5. Layout Peta untuk Stage Game

Berdasarkan Gambar 5, menunjukkan perancangan dari layout untuk stage. Peta level ini digunakan untuk menunjukkan kepada user sampai pada level berapa. Selain itu juga menunjukkan berapa level yang harus ditempuh oleh user untuk menyelesaikan game IDO. Setelah Game IDO menunjukkan level yang harus ditempuh oleh user, maka user akan masuk ke halaman kuis kosa kata. Adapun perancangan layout halaman kuis ditunjukkan pada Gambar 6.

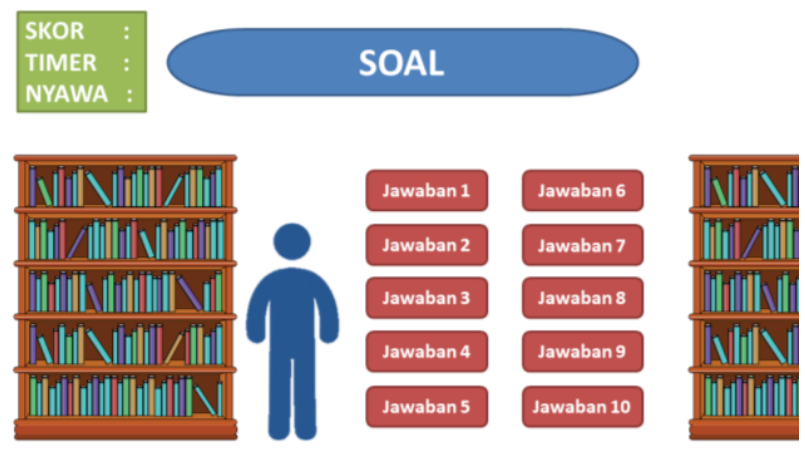

Gambar 6. Halaman Kuis Kosa Kata

Gambar 6 menunjukkan halaman kuis yang harus di lalui user. Halaman kuis digambarkan pada sebuah perpustakaan. Ketika user memasuki halaman kuis, maka di bagian SOAL akan muncul pertanyaan-pertanyaan bahasa inggris, dimana pilihan jawaban ada di bagian jawaban 1 sampai dengan jawaban 10. Halaman kuis yang terbagi menjadi 3 level, dimana kesulitan ada pada soal. Contoh soal yang muncul ketika user menempuh kuis Level 1, Level 2, dan Level 3, ditunjukkan pada Tabel 1, Tabel 2, dan Tabel 3.

Tabel 1. Contoh Kuis Level 1 Bidang Informatika dan Menejemen

\begin{tabular}{lc}
\hline \multicolumn{1}{c}{ Pertanyaan untuk Bidang Informatika } & Jawaban \\
\hline $\begin{array}{l}\text { 1. The part of a computer (a } \\
\text { microprocessor chip) that does most } \\
\text { of the data processing }\end{array}$ & CPU \\
\hline $\begin{array}{l}\text { 2. Display consisting of a device that } \\
\text { takes signals from a computer and } \\
\text { displays them on a CRT screen }\end{array}$ & Monitor \\
\hline $\begin{array}{l}\text { 3. Refers the first co letters in the left } \\
\text { corner of the keyboard the most } \\
\text { common keyboard }\end{array}$ & $\begin{array}{c}\text { Qwerty } \\
\text { Keyboard }\end{array}$ \\
\hline $\begin{array}{l}\text { 4. A hand-operated electronic device } \\
\text { that controls the coordinates of a } \\
\text { cursor on your computer screen as }\end{array}$ & Mouse \\
you move it around on a pad & \\
\hline
\end{tabular}


5. An output device that allows you to hear voice, music, and other sounds from your computer.

\section{Pertanyaan untuk Bidang Menejemen Jawaban}

Speaker

1. Raw materials supplied by nature that come from the earth, the water, or the air and are used to produce goods.

2. Someone who organizes a business venture and assumes the risk for it. A person that starts his/her own business

3. A person who uses goods or services

Consumer

4. Involving financial matters

5. A useful or valuable quality Fiscal

Tabel 2. Contoh Kuis Level 2 Bidang Informatika dan Menejemen

Pertanyaan untuk Bidang Informatika Jawaban

1. Data base is a collection of Data electronically stored

2. Drag and Drop are feature that allows Device a user to select text using a mouse or pointing , and quickly move it to a different location

3. A program that secretly attaches Viruses itself to a legitimate "carrier" such as a document or program, and then executes when document is opened or program is launched called by

4. Malware software is designed to Software infiltrate or damage a computer system without the user's informed consent, designed to infiltrate or damage a computer system without the user's informed consent

5. Internet service is Providers companies that offer internet connections at monthly rates depending on the kind and amount of access needed Pertanyaan untuk Bidang Ekonomi Jawaban

1. that states that the price of Supply and a good rises and falls depending on demand how many people want it (demand) concept and depending on how much of the good is available (supply)

2. __ is a business organization Partnership owned by two or more persons who agree on a specific division of responsibilities and profits

3. Business organization is an Commercial establishment formed to carry on enterprise

4. General partnership is in Partnership which partners share equally in both responsibility and liability

$5 . \quad$ money and other valuables Assets


belonging to an individual or business

Tabel 3. Contoh Kuis Level 2 Bidang Informatika dan Menejemen

\begin{tabular}{|c|c|}
\hline Pertanyaan untuk Bidang Informatika & Jawaban \\
\hline $\begin{array}{l}\text { 1. Basic Start-Menu option- user can } \\
\text { input commands to run specific } \\
\text { programs }\end{array}$ & Run \\
\hline $\begin{array}{l}\text { 2. Many programs and applications run } \\
\text { within these. They can be opened, } \\
\text { minimized, resized, and closed }\end{array}$ & Windows \\
\hline
\end{tabular}

3. This is located on the right side of a window when the window contains more information than can fit on one Scroll Bar screen. Moving it up and down allows you to see it all

4. Your system needs to have at least Minimum this much speed, memory, space, etc. System To run the software properly Requiremen

\begin{tabular}{ll}
\hline $\begin{array}{l}\text { 5rograms will run on a system with } \\
\text { the minimum requirements, but will } \\
\text { run better at this in order to get } \\
\text { optimum software performance }\end{array}$ & $\begin{array}{c}\text { ts } \\
\text { Recommen } \\
\text { dations }\end{array}$ \\
\hline $\begin{array}{l}\text { Pertanyaan untuk Bidang Ekonomi } \\
\text { 1. The annual income earned by a } \\
\text { nation's firms and citizens }\end{array}$ & $\begin{array}{c}\text { Jawaban } \\
\text { national } \\
\text { product }\end{array}$ \\
\hline $\begin{array}{l}\text { The loss of the value of capital } \\
\text { equipment that results from normal } \\
\text { wear and tear }\end{array}$ & $\begin{array}{c}\text { Depreciatio } \\
\mathrm{n}\end{array}$ \\
\hline $\begin{array}{l}\text { The average of all prices in the } \\
\text { economy }\end{array}$ & Price level \\
\hline $\begin{array}{l}\text { A period of macroeconomic } \\
\text { expansion followed by one of } \\
\text { macroeconomic contraction }\end{array}$ & $\begin{array}{c}\text { Business } \\
\text { cycle }\end{array}$ \\
\hline $\begin{array}{l}\text { 5. } \\
\text { A period of economic growth as } \\
\text { measured by a rise in real GDP }\end{array}$ & Expansion \\
\hline
\end{tabular}

\section{Tahap Implementasi}

Tahap ketiga adalah implementasi. Pembuatan game IDO menggunakan software construct 2 , kemudian dijalankan di browser sebelum aplikasi (.exe) dibuat. Implementasi game IDO ini dibuat berdasarkan rancangan yang dibuat sebelumnya. Pada tahap ini juga melakukan evaluasi perancangan yang dibuat.

Pembuatan Game IDO dimulai dengan masukkan semua obyek (sprite) ke dalam project. Setelah itu diberikan action pada setiap obyek. Pengaturan tampilan home ditunjukkan pada Gambar 7. 


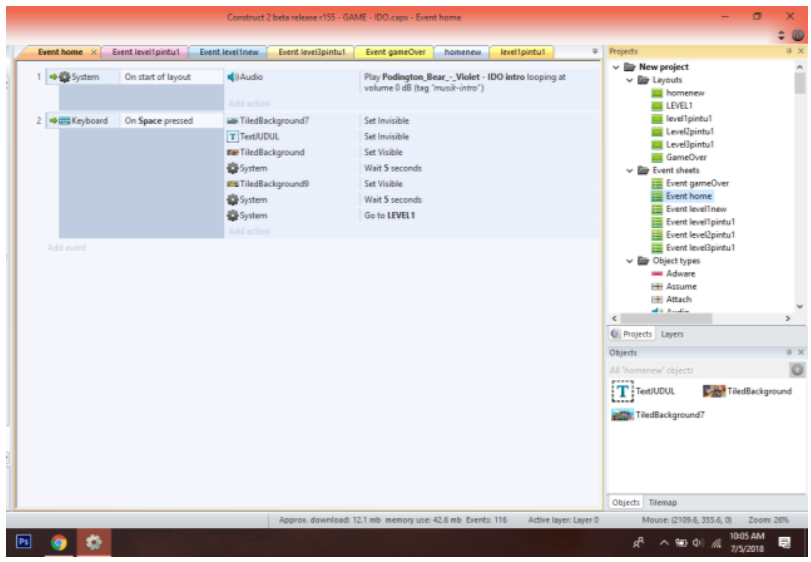

Gambar 7. Pengaturan Halaman Judul

Berdasarkan gambar 7, setiap object diberikan action dan event. Salah satunya yaitu pengaturan home. Ketika Space keyboard di tekan, maka halaman home akan menuju halaman selanjutnya. Adapun Proses desain object pada layout harus ditentukan terlebih dulu. Contoh pengaturan layout untuk halaman kuis ditunjukkan pada Gambar 8.

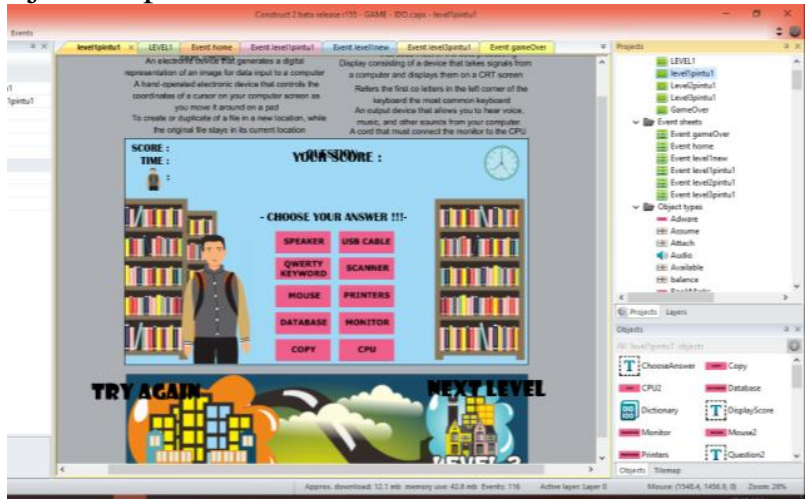

Gambar 8. Pengaturan Layout Halaman Kuis

Dari gambar 8 menunjukkan pengaturan object yang diinputkan ke dalam halaman kuis. Ada beberapa object pertanyaan dan jawaban. Pertanyaan akan muncul secara berurutan berdasarkan pengaturan waktu. Setelah user menyelesaikan kuis akan muncul skor yang di dapatkan. Kemudian user akan diberikan pilihan, ingin melanjutkan level selanjutnya, atau ingin mengulang level tersebut. Adapun potongan action script dari halaman kuis ditunjukkan pada Gambar 9.

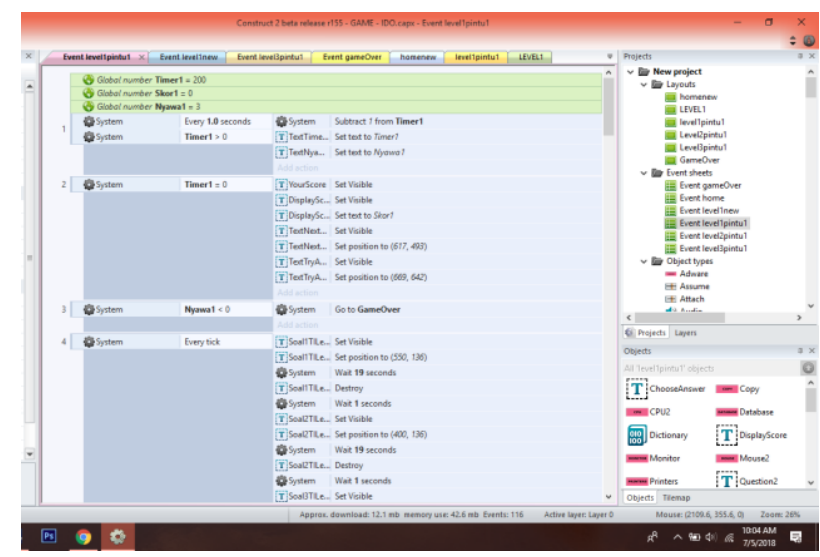

Gambar 9. Action Script Halaman Kuis 
Berdasarkan Gambar 9, menunjukkan pengaturan setiap berapa detik soal muncul di halaman kuis, dan setelah 20 detik, soal akan berganti dengan soal yang lain.

\section{Tahap Pengujian}

Tahap keempat yang dibuat adalah pengujian. Pengujian game IDO sangat perlu dilakukan untuk mengetahui kelayakan dari game tersebut. Pengujian dilakukan oleh 2 orang pakar. Tahap pengujian dilakukan menggunakan black box testing yang berfokus pada persyaratan fungsional. Sehingga, fitur-fitur dan fungsi-fungsi pada game IDO sesuai dengan rancangan yang dibuat.

\section{Tahap Pengoperasian dan Maintenance}

Tahap kelima merupakan pengoperasian dari game IDO. Game IDO dijalankan oleh mahasiswa STMIK dan STIE ASIA Malang saat menempuh mata kuliah bahasa inggris. Selama pengoperasian game IDO juga dilakukan maintenance untuk menghindari terjadinya error pada game ketika dijalankan. Selain itu, juga dilakukan penambahan kosa kata baru yang lebih relevan.

\section{Hasil dan Pembahasan}

Saat ini game tidak hanya digunakan untuk mengisi waktu luang atau melakukan hobi, namun juga untuk mengembangkan kreatifitas serta intelektual pengguna [11]. Pada penelitian ini terdapat 2 buah game edukasi kosa kata yaitu bidang informatika dan bidang menejemen. Pada game English With Ido bidang informatika maka user akan dihadapkan pada soal-soal evaluasi kosa kata bahasa inggris pada bidang teknik infomatika, begitu juga ketika menjalankan game English With Ido bidang menejemen, Ido dihadapkan dengan soal-soal evaluasi kosa kata bahasa inggris pada bidang menejemen. Game yang dihasilkan pada penelitian ini dijalankan pada platform desktop. Hal tersebut dikarenakan game Anglish With Ido lebih utama diaplikasikan di dalam kelas.

Satu karakter Ido yang dibuat terdiri dari beberapa gambar. Sehingga, ketika Ido berhenti, berjalan, maupun melompat tidak tampak kaku. Gambar 10 menunjukkan karakter IDO ketika berhenti/diam.

$$
1111111
$$

Gambar 10. Karakter Ido Posisi Diam

Gambar 11 menunjukkan ketika karakter Ido melompat. Ketika Ido berjalan ditunjukkan pada Gambar 12. Ketika Ido terjatuh ditunjukkan pada Gambar 13, dan ketika Ido berhasil menyelesaikan kuis pada ketiga level, maka Ido akan menunjukkan rasa senang yang digambarkan pada Gambar 14.

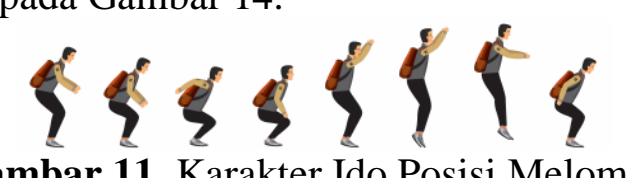

Gambar 11. Karakter Ido Posisi Melompat
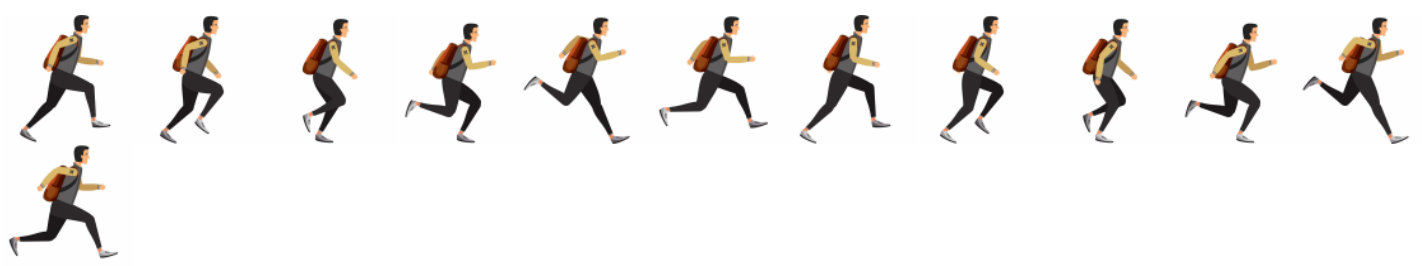

Gambar 12. Karakter Ido Posisi Berlari

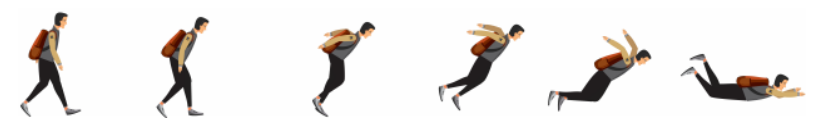

Gambar 13. Karakter Ido Posisi Terjatuh 


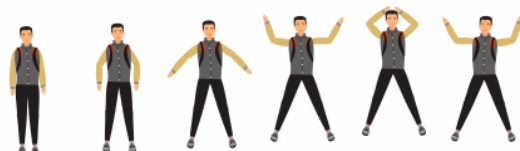

Gambar 14. Karakter Ido Ketika Berhasil

Pada pengembangan game kosa kata bahasa inggris menggunakan Construct 2. Judul game yang dikembangkan adalah "English With Ido". Adapun tampilan home ditunjukkan pada Gambar 15.

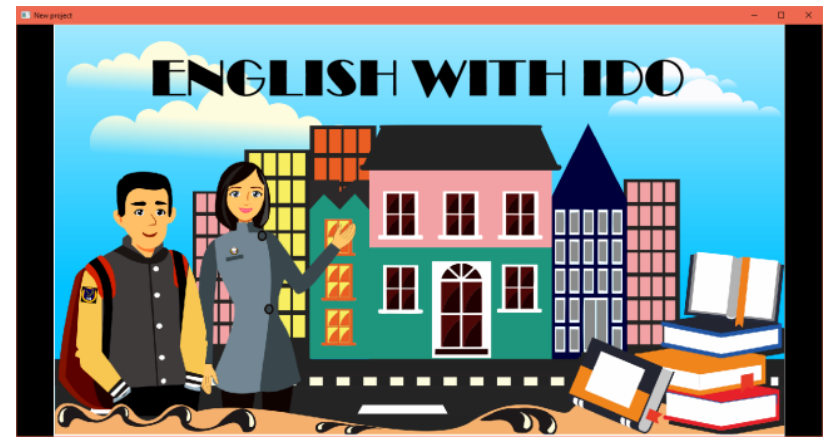

Gambar 15. Tampilan Halaman Home

Pada Gambar 15 menunjukkan halaman home dimana menampilkan gambaran mahasiswa, dosen, dan tumpukan buku. Untuk melanjutkan ke halaman selanjutnya dapat klik "space" pada keyboard. Setelah itu game akan masuk ke halaman story yang ditunjukkan pada Gambar 16.

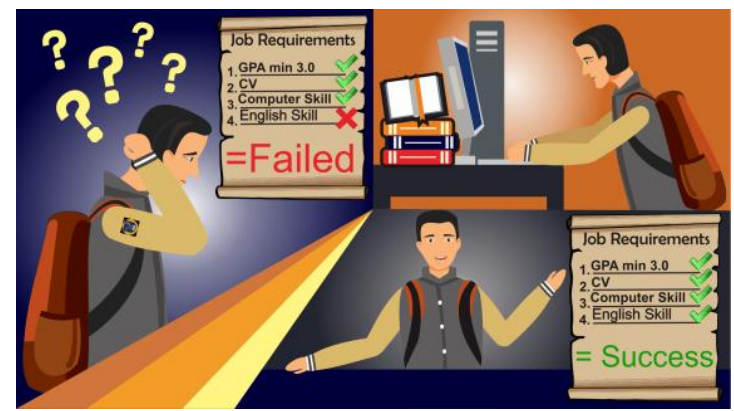

Gambar 16. Tampilan Halaman Story

Gambar 16 menunjukkan cerita dari tujuan mahasiswa menggunakan game ini. Dari halaman tersebut menceriterakan bahwa seorang mahasiswa merasa kesulitan dalam bahasa inggris ketika mendapati persyaratan mencari kerja. Kemudian mahasiswa tersebut berusaha belajar kosa kata bahasa inggris menggunakan game ini. Sehingga, mahasiswa lebih memahami kosa kata untuk lolos ujian dalam persyaratan mencari kerja. Untuk menuju ke halaman selanjutnya adalah dengan menekan "space" pada keyboard. Pada game ini akan menampilkan halaman study, dimana user dapat berlatih kosa kata. Halaman study ditunjukkan pada Gambar 17.

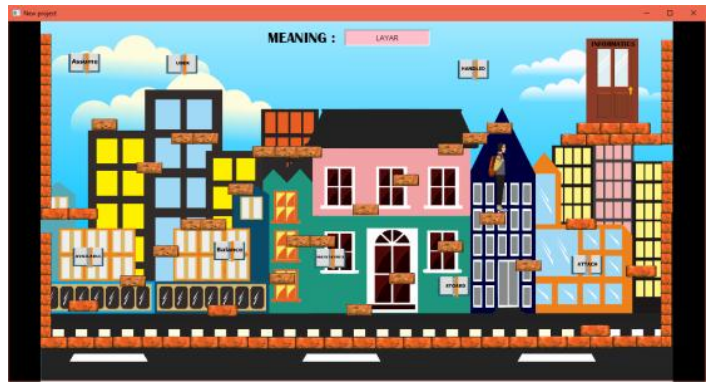

Gambar 17. Halaman Study 
Pada Gambar 17 sprite game, yaitu Ido, menggunakan behaviors platform. Sehingga langsung dapat dioperasikan dengan keyboard menggunakan tombol panah kiri, kanan, maupun atas. Pada halaman study Ido dapat berlatih kosa kata yang ada tertulis pada bukubuku tersebut. Untuk menampilkan arti kosa katanya, Ido harus mengambil buku tersebut satu demi satu kemudian melihat artinya di bagian textbox Meaning.

User harus masuk ke dalam pintu untuk masuk ke halaman evaluasi kosa kata di level 1, level 2, dan level 3. Selanjutnya muncul peta level dari keseluruhan game, yaitu level 1, 2, dan 3. Untuk level 1, maka tampilan peta ditunjukkan pada Gambar 18.

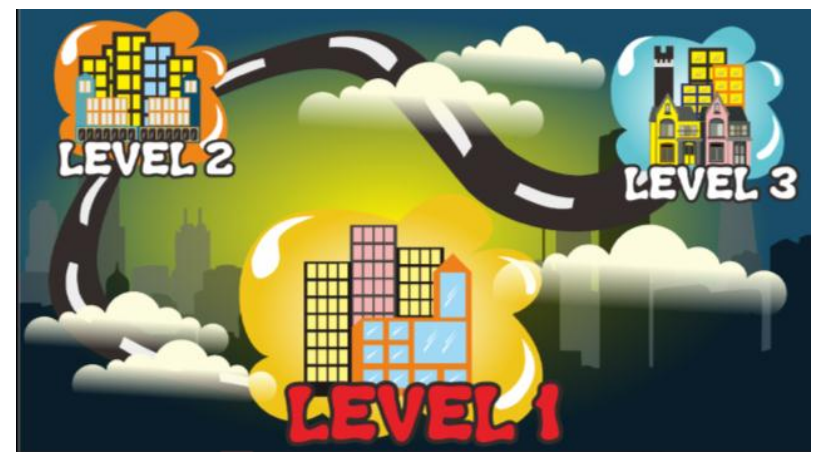

Gambar 18. Tampilan Peta Level 1

Pada Gambar 18 menunjukkan petal level 1, sehingga pada gedung level 1 terlihat lebih besar dibandingkan yang lainnya. Begitu juga pada peta level 2 dan level 3 tampilan gedung lebih besar dari pada yang lainnya. Setelah game menampilkan halaman level, selanjutnya user dapat masuk halaman evaluasi yaitu level 1, 2, dan 3 dengan menekan "space" pada keyboard.

Pada saat menjalankan game bidang informatika halaman evaluasi ditunjukkan pada Gambar 19, dan ketika memasuki bidang menejemen ditunjukkan pada Gambar 20. Situasi yang sama juga ditunjukkan pada level 2 dan level 3 ketika menjalankan game bidang informatika dan menejemen.

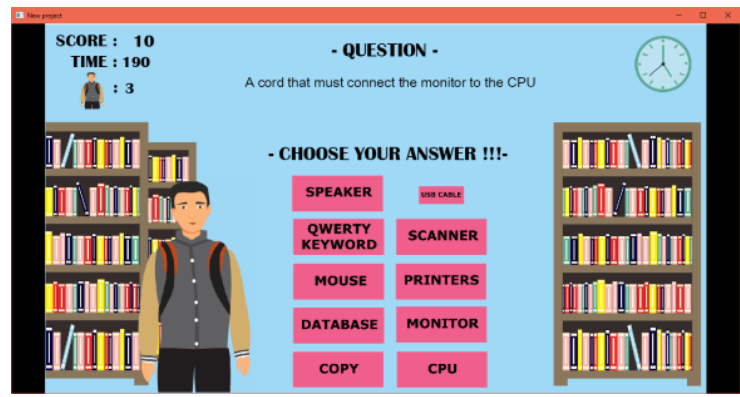

Gambar 19. Halaman Kuis Informatika Level 1

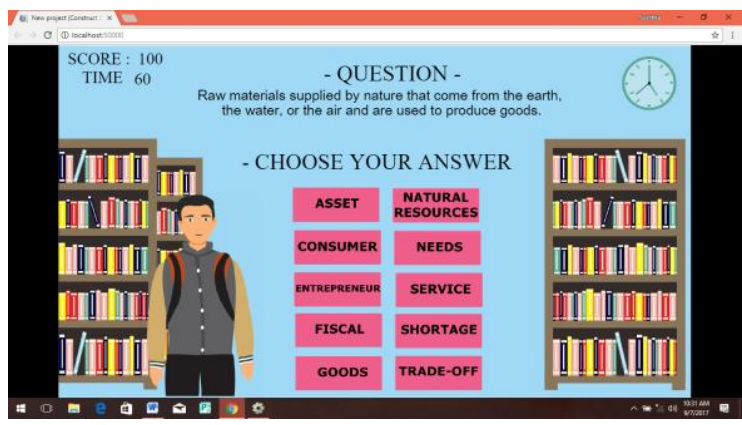

Gambar 20. Halaman Kuis Menejemen Level 1 
Setiap soal akan keluar secara bergantian. Ketika soal muncul maka Ido harus memilih pilihan jawaban yang tersedia. Pada level 1 ini, terdapat suatu deskripsi dari objek maupun kata kerja tertentu. Sehingga, Ido harus dapat menyimpulkan jawaban dari deskripsi tersebut. Pada saat melakukan evaluasi di pintu menejemen juga melakukan hal yang sama. Waktu yang dibutuhkan untuk menyelesaikan soal di level 1 adalah 150 detik.

Berbeda dengan soal evaluasi pada level 1, pada level 2 Ido menyelesaikan soal dengan cara mengisi kalimat yang kosong. Cara yang dilakukan sama dengan evaluasi di level 1, yaitu dengan memilih salah satu jawaban yang dianggap paling benar. Waktu yang dibutuhkan untuk menyelesaikan soal level 2 adalah 200 detik. Jika jawaban benar, maka score bertambah 10. Waktu yang diberikan untuk menyelesaikan level 3 adalah 250 detik.

Evaluasi pada level 1, 2, dan 3 pada game bidang informatika dan menejemen memiliki cara pengoperasian yang sama, yaitu terdapat pilihan jawaban pada setiap soal yang akan keluar secara bergantian. Ketika soal muncul, maka Ido harus memilih pilihan jawaban yang paling tepat. Jika benar, maka score akan bertambah 10 point. Saat Ido dapat menyelesaikan semua soal, maka muncul nilai total yang diperoleh. Selain itu juga pada game ini akan menawarkan 2 pilihan yaitu apakah Ido mengulang mengerjakan di level yang sama atau ingin melanjutkan ke level berikutnya yang ditunjukkan pada Gambar 21.

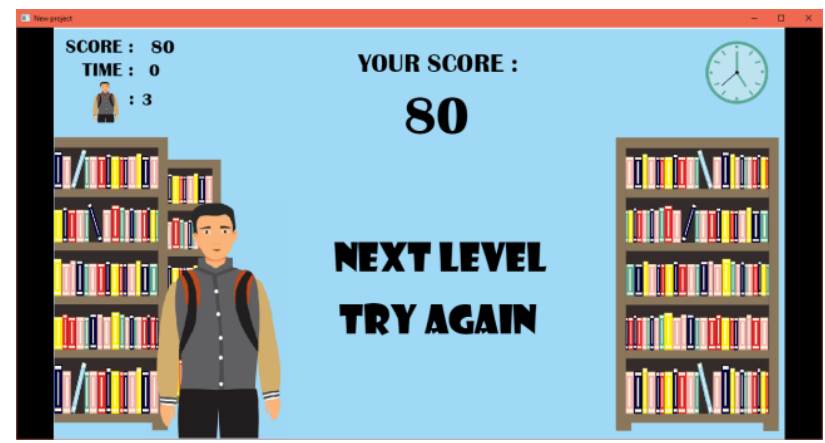

Gambar 21. Halaman Skor

Ketika ido berhasil menyelesaikan semua evaluasi dengan baik, maka di akhir game ini muncul halaman congrats, sebagai tanda keberhasilan Ido, yang ditunjukkan pada Gambar 22.

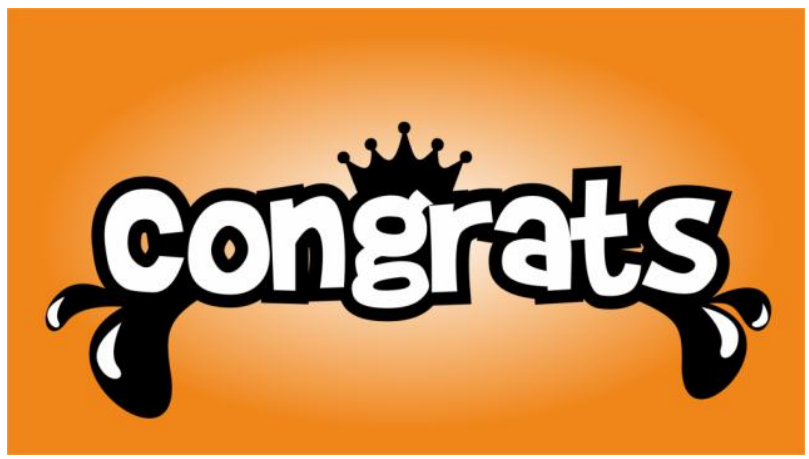

Gambar 22. Halaman Congrats

Kesempatan atau nyawa Ido dalam setiap level adalah 3. Nyawa dari ido didapatkan berdasar waktu. Jika waktu habis maka nyawa Ido akan berkurang 1. Jika nyawa habis, maka game akan menuju ke halaman Game Over.

Pengujian yang dilakukan pada penelitian ini adalah pengujian fungsional untuk menunjukkan bahwa spesifikasi dan scenario aplikasi sesuai [2]. Pengujian fungsional dilakukan untuk menguji setiap tombol navigasi pada Game English With Ido telah berfungsi dengan baik secara keseluruhan. Adapun pengujian fungsional Game English With Ido ditunjukkan pada Tabel 4. 
Tabel 4. Pengujian Tombol Navigasi Game

\begin{tabular}{|c|c|c|c|}
\hline No & Komponen & $\begin{array}{c}\text { Keterangan/Action } \\
\text { Komponen }\end{array}$ & Status \\
\hline 1 & $\begin{array}{l}\text { Tombol } \\
\text { Space }\end{array}$ & $\begin{array}{l}\text { Dari halaman judul } \\
\text { bisa masuk ke } \\
\text { halaman story }\end{array}$ & Berhasil \\
\hline 2 & $\begin{array}{l}\text { Right } \\
\text { Arrow }\end{array}$ & $\begin{array}{l}\text { Ido dapat berpindah } \\
\text { posisi ke kanan }\end{array}$ & Berhasil \\
\hline 3 & Left Arrow & $\begin{array}{l}\text { Ido dapat berpindah } \\
\text { posisi ke kiri }\end{array}$ & Berhasil \\
\hline 4 & Up Arrow & Ido dapat melompat & Berhasil \\
\hline 5 & $\begin{array}{l}\text { Buku } \\
\text { Available }\end{array}$ & $\begin{array}{l}\text { Dapat menampilkan } \\
\text { arti dari available ke } \\
\text { dalam } \\
\text { meaning }\end{array}$ & Berhasil \\
\hline 6 & $\begin{array}{l}\text { Buku } \\
\text { Assume }\end{array}$ & $\begin{array}{lr}\text { Dapat menampilkan } \\
\text { arti dari } \\
\text { dalam } \\
\text { meaning }\end{array}$ & Berhasil \\
\hline 7 & Buku User & \begin{tabular}{lr}
\multicolumn{2}{c}{ Dapat menampilkan } \\
arti dari & user ke \\
dalam & kotak \\
meaning &
\end{tabular} & Berhasil \\
\hline 8 & $\begin{array}{l}\text { Buku } \\
\text { Balance }\end{array}$ & $\begin{array}{lr}\text { Dapat menampilkan } \\
\text { arti dari balance ke } \\
\text { dalam } \\
\text { meaning }\end{array}$ & Berhasil \\
\hline 9 & $\begin{array}{l}\text { Buku } \\
\text { Maintained }\end{array}$ & $\begin{array}{l}\text { Dapat menampilkan } \\
\text { arti dari maintained } \\
\text { ke dalam kotak } \\
\text { meaning }\end{array}$ & Berhasil \\
\hline 10 & $\begin{array}{l}\text { Buku } \\
\text { Handled }\end{array}$ & $\begin{array}{lr}\text { Dapat menampilkan } \\
\text { arti dari handled ke } \\
\text { dalam } \\
\text { meaning }\end{array}$ & Berhasil \\
\hline 11 & $\begin{array}{l}\text { Buku } \\
\text { Stored }\end{array}$ & $\begin{array}{lr}\text { Dapat menampilkan } \\
\text { arti dari } & \text { stored ke } \\
\text { dalam } & \text { kotak } \\
\text { meaning } & \end{array}$ & Berhasil \\
\hline 12 & $\begin{array}{l}\text { Buku } \\
\text { Attach }\end{array}$ & $\begin{array}{lr}\text { Dapat menampilkan } \\
\text { arti dari } \\
\text { dalam } & \text { kotak ke } \\
\text { meaning } & \end{array}$ & Berhasil \\
\hline 13 & $\begin{array}{l}\text { Pintu } \\
\text { informatics/ } \\
\text { manajement }\end{array}$ & $\begin{array}{l}\text { Ido dapat memasuki } \\
\text { pintu untuk masuk } \\
\text { ke halaman level } 1\end{array}$ & Berhasil \\
\hline 14 & $\begin{array}{l}\text { Waktu } \\
\text { otomatis } \\
\text { halaman } \\
\text { level }\end{array}$ & $\begin{array}{l}\text { Game menunjukkan } \\
\text { pada level berapa } \\
\text { user berada. Setelah } \\
5 \text { detik otomatis } \\
\text { game akan masuk } \\
\text { ke level } 1\end{array}$ & Berhasil \\
\hline 15 & Random & Setelah & Berhasil \\
\hline
\end{tabular}




\begin{tabular}{|c|c|c|c|}
\hline No & Komponen & $\begin{array}{c}\text { Keterangan/Action } \\
\text { Komponen }\end{array}$ & Status \\
\hline & Question & beberapa detik soal & \\
\hline & Level 1, & otomatis & \\
\hline & Level & berganti dengan soal & \\
\hline & dan Level 3 & yang lain. Setiap & \\
\hline & & $\begin{array}{l}\text { Level diberikan } 10 \\
\text { soal }\end{array}$ & \\
\hline \multirow[t]{2}{*}{16} & Text Score & Otomatis akan & Berhasil \\
\hline & & $\begin{array}{l}\text { bertambah } 10 \text { poin } \\
\text { jika user memilih } \\
\text { jawaban yang benar }\end{array}$ & \\
\hline \multirow[t]{6}{*}{17} & Text Time & Secara otomatis & Berhasil \\
\hline & \& Nyawa & berkurang & \\
\hline & & setiap detik. Jika & \\
\hline & & waktu $=0$, maka & \\
\hline & & nyawa akan & \\
\hline & & berkurang 1. & \\
\hline \multirow[t]{6}{*}{18} & Tombol & User memilih sesuai & Berhasil \\
\hline & Answer & pertanyaan & \\
\hline & & diberikan. & \\
\hline & & kursor diarahkan ke & \\
\hline & & Tombol Answer, & \\
\hline & & $\begin{array}{l}\text { maka ukuran akan } \\
\text { lebih kecil. }\end{array}$ & \\
\hline \multirow[t]{2}{*}{19} & Tombol & Menuju ke halaman & Berhasil \\
\hline & Next Level & level selanjutnya & \\
\hline \multirow[t]{2}{*}{20} & Tombol Try & Mengulang & Berhasil \\
\hline & Again & $\begin{array}{l}\text { pada level yang } \\
\text { sama }\end{array}$ & \\
\hline \multirow[t]{3}{*}{21} & Halaman & Muncul setelah user & Berhasil \\
\hline & Congrats & menyelesaikan kuis & \\
\hline & & $\begin{array}{l}\text { pada level } 1 \text {, level } 2 \text {, } \\
\text { dan level } 3 \text {. }\end{array}$ & \\
\hline \multirow[t]{2}{*}{22} & Halaman & Muncul ketika text & Berhasil \\
\hline & Game Over & nyau & \\
\hline 23 & Backsound & Sound & Berhasil \\
\hline & & berjalan ketika & \\
\hline & & game dijalankan & \\
\hline
\end{tabular}

Pengujian kedua dilakukan dengan cara kuisioner kepada 70 mahasiswa yang sedang dan telah menempuh matakuliah bahasa inggris. Adapun aspek penilaiannya berupa tampilan game, durasi waktu, daya tarik mahasiswa untuk belajar, kemudahan belajar, dan pentingnya game kosa kata (isi kosa kata). Nilai dari setiap aspek menggunakan skala likert. Skala likert merupakan skala yang digunakan untuk pengukuran hasil pendapat dari survey [3]. Setiap aspek penilaian memiliki 4 tingkat penilaian, yaitu sangat setuju (5 poin), setuju (4 poin), kurang setuju (3 poin), tidak setuju ( 2 poin), dan sangat tidak setuju (1 poin). Adapun grafik prosentase tampilan game ditunjukkan pada Gambar 24, prosentase durasi waktu ditunjukkan pada Gambar 25, prosentase daya tarik mahasiswa untuk belajar ditunjukkan pada Gambar 26, prosentase kemudahan belajar ditunjukkan pada Gambar 27, dan prosentase pentingnya game kosa kata (isi kosa kata) ditunjukkan pada Gambar 28. 


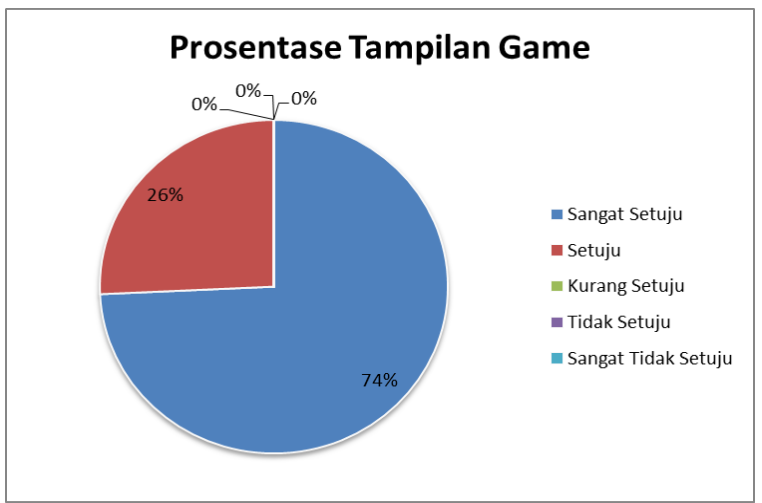

Gambar 24. Prosentase Tampilan Game

Berdasarkan Gambar 24, responden menyatakan sangat setuju dengan tampilan Game English with Ido sebesar 74\%, dan menyatakan setuju sebesar $26 \%$.

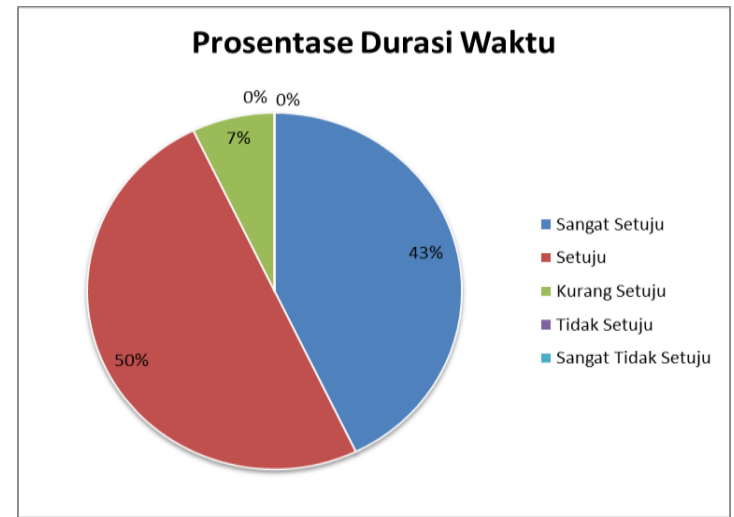

Gambar 25 Prosentase Durasi Waktu

Berdasarkan Gambar 25, reponden menyatakan sangat setuju sebesar $43 \%$ dari durasi game, mulai start game sampai dengan menyelesaikan kuis di level 3. Responden yang menyatakan setuju sebanyak 50\%, sedangkan yang menyatakan kurang setuju sebanyak $7 \%$.

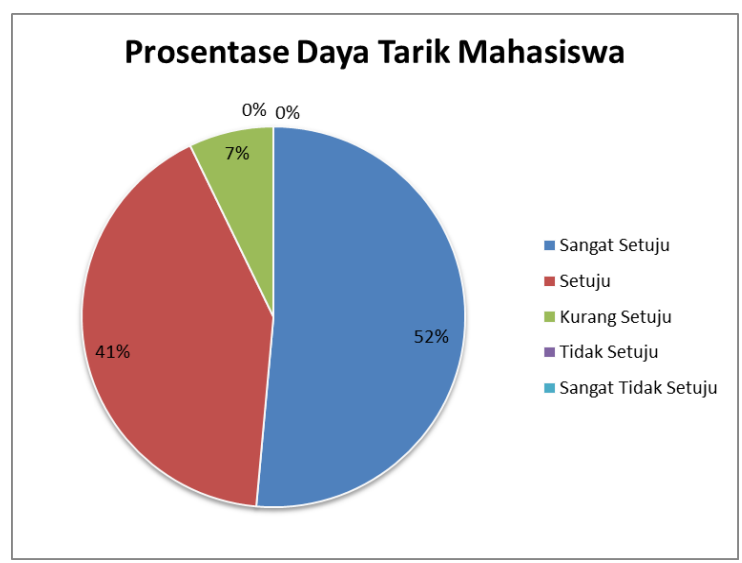

Gambar 26 Prosentase Daya Tarik Mahasiswa

Daya tarik mahasiswa terhadap Game English with Ido sebagian besar responden menyatakan sangat setuju, sebesar 52\%. $41 \%$ menyatakan setuju, dan $7 \%$ menyatakan kurang setuju. 


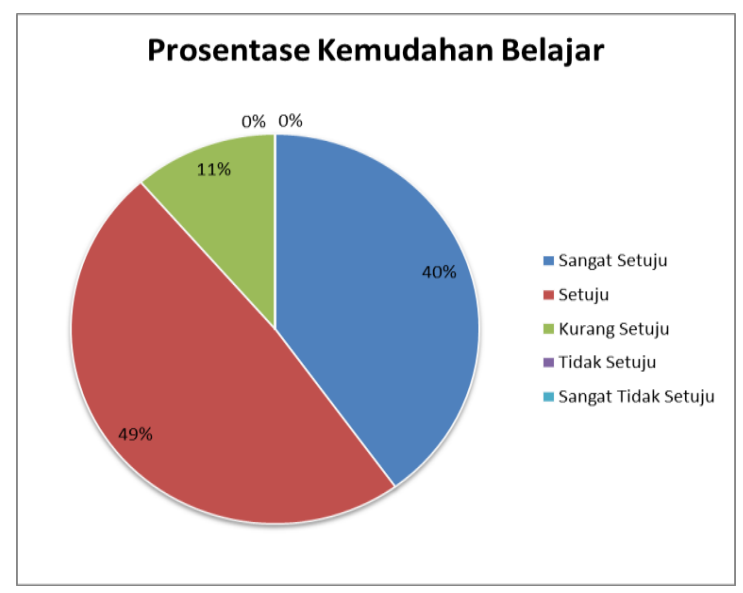

Gambar 27. Prosentase Kemudahan Belajar

Berdasarkan Gambar 27 menunjukkan prosentase kemudahan belajar kosa kata bahasa inggris. Responden menyatakan sangat setuju bahwa Game English With Ido memudahkan belajar kosa kata bahasa inggris sebesar 40\%, setuju sebesar 49\%, dan kurang setuju sebesar $11 \%$.

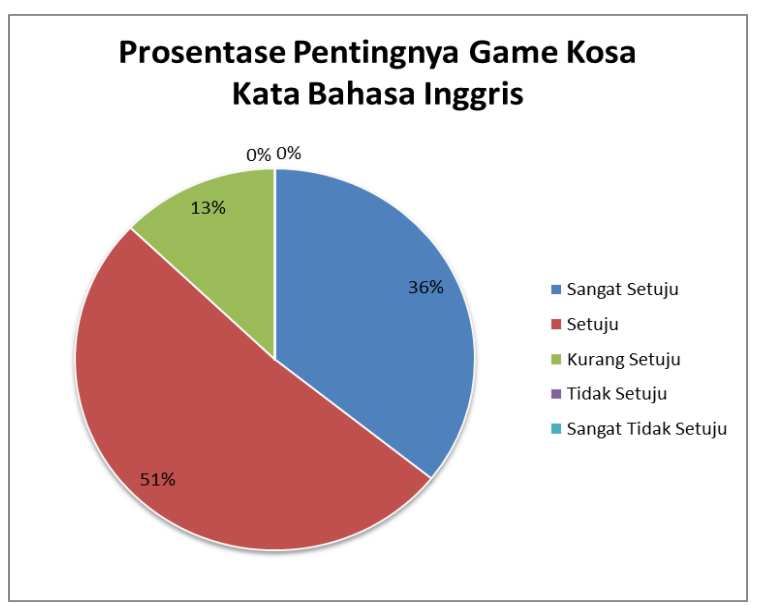

Gambar 28. Prosentase Pentingnya Game Kosa Kata Bahasa Inggris

Gambar 28 menunjukkan prosentase pentingnya game kosa kata bahasa inggris menurut mahasiswa. Setelah menjalankan Game English With Ido 36\% responden menyatakan sangat setuju, 51\% menyatakan setuju, dan 13\% menyatakan kurang setuju

\section{KESIMPULAN}

Bahasa inggris telah menjadi kebutuhan masyarakat. Selain pendidikan dan kehidupan social, bahasa inggris juga menjadi salah satu persyaratan dalam mencari pekerjaan. Sampai saat ini bahasa inggris masih menjadi beban mahasiswa. Salah satu kesulitan mahasiswa adalah kesulitan dalam memahami kosa kata. Oleh karena itu dibuat game edukasi kosa kata bahasa inggris untuk meningkatkan kemampuan kosa kata bahasa inggris mahasiswa. Adapun nama game edukasi yang dikembangkan dalam penelitian ini adalah English With Ido. Metode yang digunakan dalam perancangan game ini menggunakan metode waterfall. Pengujian game ini dilakukan secara uji fungsional, yaitu untuk mengetahui semua tombol dan menu pada game telah berjalan dengan baik. Selain itu pengujian game ini dilakukan dengan kuisioner dengan jumlah 70 responden. Adapun prosentase berupa aspek penilaian tampilan game menyatakan sangat setuju sebesar $74 \%$, prosentase durasi waktu menyatakan setuju sebesar $50 \%$, prosentase daya tarik mahasiswa untuk belajar menyatakan sangat setuju sebesar 52\%, prosentase kemudahan belajar menyatakan setuju sebesar $49 \%$, dan pentingnya game kosa kata menyatakan setuju 
sebesar $51 \%$. Secara keseluruhan responden menyatakan setuju dan sangat setuju dari penerapan game English With Ido

\section{DAFTAR PUSTAKA}

Rahadi, Muhammad Rizky. Satoto, Kodrat Iman. Windasari, Ike Pertiwi. "Perancangan Game Math Adventure Sebagai Media Pembelajaran Matematika Berbasis Android". Jurnal Teknologi dan Sistem Komputer, Vol. 4 No. 1 e-ISSN : 2338-0403), Januari 2016

Defrianto, Dony. Kridalukmana, Rinta. Windasari, Ike Pratiwi. "Pengembangan Permainan Edukatif Ragam Budaya Nusantara Berbasis Android". Jurnal Teknologi dan Sistem Komputer, Vol. 3 No. 3 e-ISSN : 2338-0403), Agustus 2015

Almikdad, An'im. Isnanto, R Rizal. Windasari, Ike Pertiwi. "Pengembangan Permainan Edukatif Tebak Bendera Berbasis Windows Phone". Jurnal Teknologi dan Sistem Komputer, Vol. 4 No. 2 e-ISSN : 2338-0403), April 2016

Setyawidi, Laras. Kridalukmana, Rinta. Martono, Kurniawan Teguh. "Pembuatan Aplikasi Permainan Ayo Sehat Berbasis Android”. Jurnal Teknologi dan Sistem Komputer, Vol. 4 No. 2 e-ISSN : 2338-0403), April 2016

David. "Perancangan Game Mobile Android Bergenre Horror". Cogito Smart Journal Vol. 2 No. 2, pp 167179, Desember 2016.

Purnomo, Fendi Aji, dkk. "Pembuatan Game Edukasi Petualangan Si Gembul Sebagai Pembelajaran Pengenalan Daerah Solo Raya Pada Anak". Jurnal Simetris Vol. 7 No.2 ISSN: 2252-4983. November 2016.

Fithri, Diana Laily. Setiawan, Dave Andre. "Analisa dan Perancangan Game Edukasi Sebagai Motivasi Belajar Untuk Anak Usia Dini”. Jurnal Simetris Vol. 8 No. 1 ISSN: 2252-4983. April 2017.

Batuwael, Edvin. Lumenta, Arie. Tulenan, Virginia. "Analisa dan Perancangan Game Edukasi Kebersihan Mulut Pada Anak Umur 5-10 Tahun Berbasis Android”. E-Journal Teknik Informatika Vol. 7 No. 1 ISSN : 2301-8364. Januari 2016.

Busran. Fitriyah. "Perancangan Permainan (Game) Edukasi Belajar Membaca Pada Anak Prasekolah Berbasis Smartphone Android (Studi Kasus : Taman Kanak-Kanak Ikal Iqra Padang Selatan)”. Jurnal Teknoif Vol. 3 No. 1 ISSN:2338-2724. April 2015.

Ashari, Yusuf. Kridalukmana, Rinta. Windasari, Ike Pertiwi. "Pembuatan Aplikasi Permainan Pengenalan Provinsi di Indonesia Melalui Game "Adventure Indonesia" Berbasis Android". Jurnal Teknologi dan Sistem Komputer, Vol. 4 No. 2 e-ISSN : 2338-0403), April 2016

Hendraputri, Annisa Hedlina. Kridalukmana, Rinta. Nurhayati, Oky Dwi. "Pengembangan Game Edukatif G30S/PKI Berbasis Android”. Jurnal Teknologi dan Sistem Komputer, Vol. 2 No. 4 e-ISSN : 23380403), Oktober 2014.

Adhanisa, Laila. Kridalukmana, Rinta, Martono, Kurniawan Teguh. "Pembuatan Permainan Lompat Karung Berbasis iOS Menggunakan Game Salad". Jurnal Teknologi dan Sistem Komputer, Vol. 4 No. 2 eISSN : 2338-0403), April 2016.

Sholikhin, Riyadhi. Nurhayati, Oky Dwi. Widianto, Eko Didik. "Pembuatan Aplikasi Permainan "Engrang Run” Berbasis Android”. Jurnal Teknologi dan Sistem Komputer, Vol. 4 No. 1 e-ISSN : 2338-0403), Januari 2016

Kurniawan, Arsi. Satoto, Kodrat Iman. Kridalukmana, Rinta. "Perancangan dan Pengembangan Permainan Jelajah Indonesia Berbasis iOS Menggunakan GameSalad". Jurnal Teknologi dan Sistem Komputer, Vol. 3 No. 1 e-ISSN : 2338-0403), Januari 2015.

Wulansari, Siti. Satoto, Kodrat Iman. Martono, Kurniawan Teguh. "Perancangan Permainan "UangAndro" Sebagai Media Pembelajaran Pengenalan Mata Uang Rupiah Pada Anak Berbasis Android". Jurnal Teknologi dan Sistem Komputer, Vol. 4 No. 2 e-ISSN : 2338-0403), April 2016.

Syahrin, Yusnia Alfi. Satoto, Kodrat Iman. Martono, Kurniawan Teguh. "Perancangan dan Pengembangan Permainan Super Sigi Menggunakan Stencyl Sebagai Media Pengenalan Menyikat Gigi”. Jurnal Teknologi dan Sistem Komputer, Vol. 3 No. 1 e-ISSN : 2338-0403), Januari 2015.

Putri, Bellia Dwi Cahya. Kridalukmana, Rinta. Widianto, Eko Didik. "Perancangan Aplikasi Permainan Multiplayer Gobak Sodor Berbasis Flash di Lingkup Jaringan Lokal". 